\title{
Emerging infectious diseases in cetaceans worldwide and the possible role of environmental stressors
}

\author{
Marie-Françoise Van Bressem ${ }^{1,12, *}$, Juan Antonio Raga ${ }^{2}$, Giovanni Di Guardo ${ }^{3}$, \\ Paul D. Jepson ${ }^{4}$, Padraig J. Duignan ${ }^{5,13}$, Ursula Siebert ${ }^{6}$, Tom Barrett ${ }^{7}$, \\ Marcos César de Oliveira Santos ${ }^{8}$, Ignacio B. Moreno ${ }^{9}$, Salvatore Siciliano ${ }^{10}$, \\ Alex Aguilar ${ }^{11}$, Koen Van Waerebeek ${ }^{12}$ \\ ${ }^{1}$ Cetacean Conservation Medicine Group (CMED/CEPEC), Bogota, Colombia \\ ${ }^{2}$ Marine Zoology Unit, Cavanilles Institute of Biodiversity and Evolutionary Biology, University of Valencia, PO Box 22085, \\ 46071 Valencia, Spain \\ ${ }^{3}$ University of Teramo, Faculty of Veterinary Medicine, Department of Comparative Biomedical Sciences, Piazza Aldo Moro, \\ 45-64100 Teramo, Italy \\ ${ }^{4}$ Institute of Zoology, Regent's Park, London NW1 4RY, UK \\ ${ }^{5}$ Department of Agriculture, Fisheries and Food, Kildare Street, Dublin 2, Ireland \\ ${ }^{6}$ Forschungs- und Technologiezentrum Westküste, Christian Albrechts University, 25761 Buesum, Germany \\ ${ }^{7}$ Institute for Animal Health, Pirbright, UK \\ ${ }^{8}$ Projeto Atlantis, Laboratório de Biologia da Conservação de Cetáceos, Departamento de Zoologia, Instituto de Biociências, \\ Universidade Estadual Paulista 'Júlio de Mesquita Filho' (UNESP), Campus de Rio Claro, 13506-900 Rio Claro, SP, Brazil \\ ${ }^{9}$ Grupo de Estudos de Mamíferos Aquáticos do Rio Grande do Sul (GEMARS) \& Departamento de Zoologia, Universidade \\ Federal do Rio Grande do Sul (UFRGS), Av. Bento Gonçalves, 9500, CEP 91501-970, Porto Alegre, RS, Brazil \\ ${ }^{10}$ Grupo de Estudos de Mamíferos Marinhos da Região dos Lagos (GEMM-Lagos), Departamento de Endemias, Escola Nacional \\ de Saúde Pública/FIOCRUZ, Rua Leopoldo Bulhões, 1480-6 andar, Manguinhos, Rio de Janeiro, RJ 21041-210, Brazil \\ ${ }^{11}$ Department of Animal Biology, Faculty of Biology, University of Barcelona, 08071 Barcelona, Spain \\ ${ }^{12}$ Centro Peruano de Estudios Cetológicos (CEPEC), Museo de Delfines, Pucusana, Lima 20, Peru \\ ${ }^{13}$ Present address: Department of Pathology, Faculty of Veterinary Science, University of Melbourne, 250 Princes Highway, \\ Werribee, Victoria 3030, Australia
}

\begin{abstract}
We reviewed prominent emerging infectious diseases of cetaceans, examined their potential to impact populations, re-assessed zoonotic risk and evaluated the role of environmental stressors. Cetacean morbilliviruses and papillomaviruses as well as Brucella spp. and Toxoplasma gondii are thought to interfere with population abundance by inducing high mortalities, lowering reproductive success or by synergistically increasing the virulence of other diseases. Severe cases of lobomycosis and lobomycosis-like disease (LLD) may contribute to the death of some dolphins. The zoonotic hazard of marine mammal brucellosis and toxoplasmosis may have been underestimated, attributable to frequent misdiagnoses and underreporting, particularly in developing countries and remote areas where carcass handling without protective gear and human consumption of fresh cetacean products are commonplace. Environmental factors seem to play a role in the emergence and pathogenicity of morbillivirus epidemics, lobomycosis/LLD, toxoplasmosis, poxvirus-associated tattoo skin disease and, in harbour porpoises, infectious diseases of multifactorial aetiology. Inshore and estuarine cetaceans incur higher risks than pelagic cetaceans due to habitats often severely altered by anthropogenic factors such as chemical and biological contamination, direct and indirect fisheries interactions, traumatic injuries from vessel collisions and climate change.
\end{abstract}

KEY WORDS: Emerging diseases - Cetaceans - Morbilliviruses - Poxviruses - Papillomaviruses · Brucella spp. - Lacazia loboi · Toxoplasma gondii · Environmental stressors · Zoonosis 


\section{INTRODUCTION}

Emerging infectious diseases (EIDs) are defined as those that (1) are newly recognized, (2) are evolving, (3) have recently shown an increase in incidence or expansion into new geographic locations or vectors, (4) have moved from one host species to another, (5) have increased in impact or severity, (6) or have undergone a change in pathogenicity (Bengis et al. 2004). EIDs are frequently the result of a change in the ecology of host and/or pathogen and are often driven by anthropogenic environmental modifications such as encroachment, animal movements across borders and global climate changes (Daszak et al. 2001, Bengis et al. 2004, Cunningham 2005, Munson et al. 2008, Datta et al. 2009, Johnson et al. 2009). Such diseases may trigger massive mortalities, constrain the growth of wild animal populations, increase the risk of extinction of small populations in combination with other factors and provoke loss of biodiversity (Plowright 1982, Thorne \& Williams 1988, Daszak et al. 2000, Johnson et al. 2009).

In recent years EIDs have been reported in several cetacean species and populations worldwide provoking large-scale die-offs, affecting reproduction, causing disfiguring skin diseases and, in some cases, zoonosis. Here we review prominent cetacean EIDs, assess their potential to significantly impact populations as well as their zoonotic risk and consider the possible role of environmental factors.

\section{VIRAL DISEASES}

\section{Cetacean morbillivirus}

Cetacean morbillivirus (CeMV) belongs to the genus Morbillivirus (single, negative-strand RNA viruses of subfamily Paramyxovirinae, family Paramyxoviridae) and includes 3 strains: the dolphin morbillivirus (DMV, first isolated in Mediterranean striped dolphins Stenella coeruleoalba; Van Bressem et al. 1991), porpoise morbillivirus ( $\mathrm{PMV}$, first isolated in harbour porpoises Phocoena phocoena from Northern Ireland; McCullough et al. 1991) and pilot whale morbillivirus (PWMV, detected by PCR in a long-finned pilot whale Globicephala melas from New Jersey, USA; Taubenberger et al. 2000).

CeMV is endemic in several species of cetaceans worldwide (Duignan et al. 1995a,b, Van Bressem et al. 2001a). Pilot whales Globicephala spp. and other gregarious species are thought to be reservoirs of infection, act as vectors and spread the virus to other species with which they associate (Duignan et al. 1995a, Van Bressem et al. 1998). In the absence of population immunity, CeMV may trigger epidemics of lethal disease characterized by pneumonia, nonsuppurative meningo-encephalitis and prominent lymphoid cell depletion (Domingo et al. 1990, Duignan et al. 1992).

PMV and DMV caused epidemics in common bottlenose dolphins Tursiops truncatus along the USA Atlantic coast in 1982, 1987 to 1988 and 1993 to 1994 (Lipscomb et al. 1994, Duignan et al. 1996, Taubenberger et al. 1996). A high percentage of the inshore $T$. truncatus off New Jersey and south to Canaveral National Seashore, Florida, USA, may have died during the 1987 to 1988 epizootic (Lipscomb et al. 1994, McLellan et al. 2002). PMV also killed an unknown number of Phocoena phocoena along the coasts of the British Isles and The Netherlands in 1988 to 1990 (Visser et al. 1993, Kennedy 1998). DMV was responsible for lethal epidemics in the Mediterranean Sea in 1990 to 1992 and again in 2006 to 2007 (Fig. 1) (Domingo et al. 1990, Van Bressem et al. 1993, Fernández et al. 2008, Raga et al. 2008).

The 1900-1992 DMV epidemic started along the central coast of Spain in 1990 and ended in Turkey and the Greek Islands in 1992, affecting predominantly Stenella coeruleoalba, currently the most abundant odontocete in the Mediterranean (Aguilar \& Raga 1993, Aguilar 2000). Sexually mature individuals suffered the highest mortality, though dependent calves also represented a significant portion of the toll, possibly indirectly because of the deaths of their mothers (Calzada et al. 1994). DMV apparently did not persist as an endemic infection in Mediterranean striped dolphins after the epidemic terminated (Van Bressem et al. 2001a), presumably because the abundance $(117880, \mathrm{CI}=68379$ to 148000$)$ in the western Mediterranean Sea (Forcada et al. 1994) was too low to support endemic infection. Large numbers of striped dolphins have died in fisheries, which has greatly reduced their numbers (Aguilar 2000).

Between October 2006 and April 2007, at least 27 Globicephala melas stranded along the southern Spanish Mediterranean coast and the Balearic Islands (Fernández et al. 2008). In early July 2007 dead or moribund Stenella coeruleoalba and G. melas were found in the Gulf of Valencia (Raga et al. 2008) (Fig. 1). Morbillivirus lesions and antigen were detected in all 9 examined G. melas and in 13 of 17 S. coeruleoalba. Fungal and bacterial superinfections were observed in 1 individual of each species. A DMV strain closely related to the virus isolated during the 1990 to 1992 epidemic was detected in 7 of $10 \mathrm{~S}$. coeruleoalba as well as in 9 G. melas by reverse transcription-PCR. (Fernández et al. 2008, Raga et al. 2008). During the summer and autumn 2007, more than $200 S$. coeruleoalba were found dead along the coasts of 


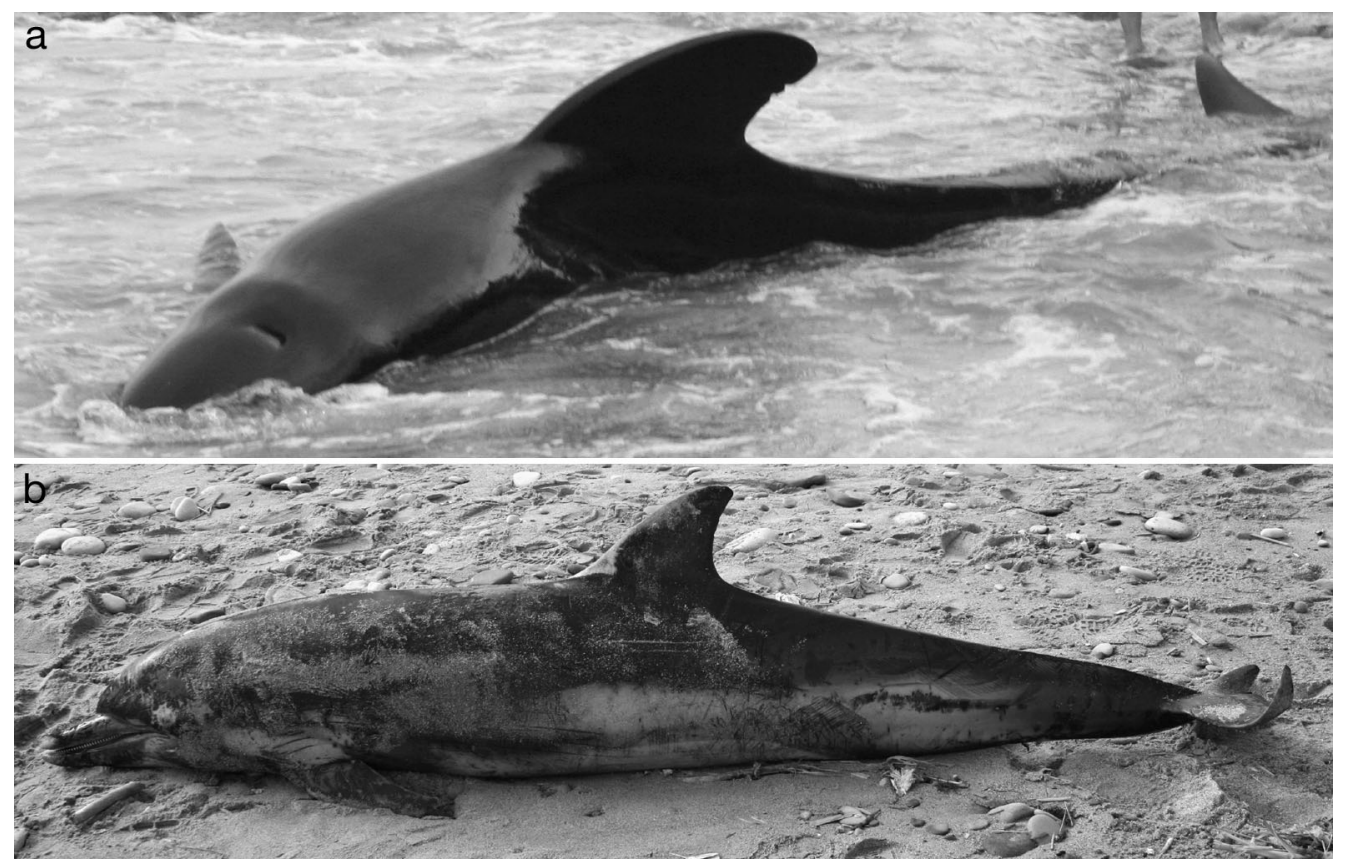

Fig. 1. (a) Globicephala melas and (b) Stenella coeruleoalba washed ashore near Valencia, Spain, during the 2006-2007 morbillivirus epidemic

Spain. Juveniles were more frequently affected (Student's test, $t=2.14$, df $=49, \mathrm{p}=0.037$ ) than adults in the 2006-2007 outbreak, probably because older dolphins were still protected by the immunity developed during the 1990-1992 epidemic (Raga et al. 2008). The virus apparently reached the French Mediterranean coast in August and Italy's Ligurian Sea coast in the period August to November 2007 (Garibaldi et al. 2008).

Taking into account that both the 1990-1992 and 2006-2007 DMV epidemics started close to, or in, the Gibraltar Strait and that DMV was circulating in the North Sea in January 2007 (Wohlsein et al. 2007), we believe that DMV-infected cetaceans, possibly Globicephala melas, entered the Strait of Gibraltar and transmitted the infection to Stenella coeruleoalba with which they occasionally form mixed groups (Raga et al. 1991). Interestingly, the outbreak of PMV mortalities in the NE Atlantic and North Sea was also contemporaneous with the 1990 to 1992 DMV epidemic (Visser et al. 1993, Kennedy 1998).

Whether some environmental factor(s) triggered or influenced these outbreaks remains to be clarified. The Stenella coeruleoalba that succumbed to the 19901992 epidemic were in a poor nutritional state, with lipid reserves estimated to be only about $60 \%$ of usual values for this population, an energy depletion that could not be explained by the effect of the disease alone (Aguilar \& Raga 1993). Also, the prevalence of ectoparasites and epibionts was much higher than reference values for this population, suggesting that dur- ing the epidemic more dolphins were susceptible to infestations, possibly because they were immunodepressed by the disease and were suffering from behavioural alterations such as reduced swimming speed (Aguilar \& Raga 1993, Aznar et al. 2005). The abnormally high sea-surface temperatures (SSTs) and low rainfall conditions in the winter preceding the 1990-1992 outbreak in the western Mediterranean apparently depressed peak productivity that occurs each year in early spring and determines the regional abundance of fish (Aguilar \& Raga 1993). This epidemic also started in regions containing unusually large numbers of inbred dolphins that were possibly more susceptible to diseases (Valsecchi et al. 2004).

Polychlorinated biphenyl (PCB) loads in Stenella coeruleoalba that died during the 1990-1992 epidemic were significantly higher (Mann-Whitney test, p < 0.001) than in individuals that survived and, given their well-known immunosuppressive effect in mammals, it was suggested that PCBs may have compromised immune response and increased the severity of the outbreak (Aguilar \& Borrell 1994). Though the role of environmental contaminants in the 2007 epidemic remains inconclusive, recent pollutant data obtained through analyses of biopsies from apparently healthy striped dolphins in 1987 to 2002 suggested that PCB and DDT concentrations have gradually decreased (Aguilar \& Borrell 2005).

Thus, several environmental factors, i.e. fisheries interactions, inbreeding, migration, high contaminant 
loads, higher SSTs and limited prey availability may have synergistically interacted to increase the severity of the disease and may favor recurrent epidemics with a profound, accumulative impact on the population dynamics of Mediterranean Stenella coeruleoalba. Morbilliviruses are generally order specific (Barrett 1999) and there are no reports of CeMV disease in humans, suggesting that CeMV is not zoonotic.

\section{Genital papillomaviruses}

Papillomaviruses (PVs), small, non-enveloped, double-stranded DNA viruses (family Papillomaviridae) are epitheliotropic pathogens that may induce proliferation of the stratified squamous epithelia of the skin and mucosae and cause lesions known as warts, papillomas and condylomas in mammals and other vertebrates (Howley \& Lowy 2001).

Genital papillomatosis has been observed in $9.7 \%$ of 31 sperm whales Physeter macrocephalus from Iceland (Lambertsen et al. 1987), in $66.7 \%$ of 78 dusky dolphins Lagenorhynchus obscurus, $50 \%$ of 10 longbeaked common dolphins Delphinus capensis, $33 \%$ of 9 Tursiops truncatus and $48.5 \%$ of 33 Burmeister's porpoises Phocoena spinipinnis from Peru (Fig. 2) (Van Bressem et al. 1996), in 3 T. truncatus from Florida (Bossart et al. 2005) and $28.7 \%$ of 251 T. truncatus from Cuba (Cruz et al. 2006), and in 1 Guiana dolphin Sotalia guianensis from Brazil (M. Marcondes pers. comm.). It was also diagnosed in captive T. truncatus in Europe and the USA (Bossart et al. 2005, Rector et al. 2008). Genital lesions macroscopically and microscopically consistent with PV-induced papillomas have also been seen in P. phocoena, short-beaked common dolphin Delphinus delphis and Stenella coeruleoalba from the British Isles (P. D. Jepson pers. obs.). Genital papillomatosis does not seem to occur in small cetaceans from New Zealand (P. J. Duignan pers. obs.) and the Spanish Mediterranean coast (J. A. Raga pers. obs.). Sexual variation in wart prevalence was found in L. obscurus and P. spinipinnis, with males being 2 and 3 times more-often infected than females, respectively (Van Bressem et al. 1996). Males may also be more frequently affected in Cuban T. truncatus (Cruz et al. 2006).

Phocoena spinipinnis papillomavirus type 1 (PsPV-1) and another still uncharacterized PV caused genital warts in P. spinipinnis (Van Bressem et al. 2007a). Three PVs (Tursiops truncatus [TtPV] papillomavirus type 1, 2 and 3) were associated with genital papillomatosis in dolphins from Europe and Atlantic USA (Rector et al. 2008). Other still uncharacterised PVs were detected in genital warts from Peruvian $T$. truncatus and Lagenorhynchus obscurus (Cassonnet et al.
1998). Recombination of an ancestor of PsPV-1 and an ancestor of TtPV-2 may have generated the common ancestor of TtPV-1 and -3 (Rector et al. 2008).

The high prevalence of genital warts in 33 Phocoena spinipinnis from Peru examined in 1993 to 1995 and
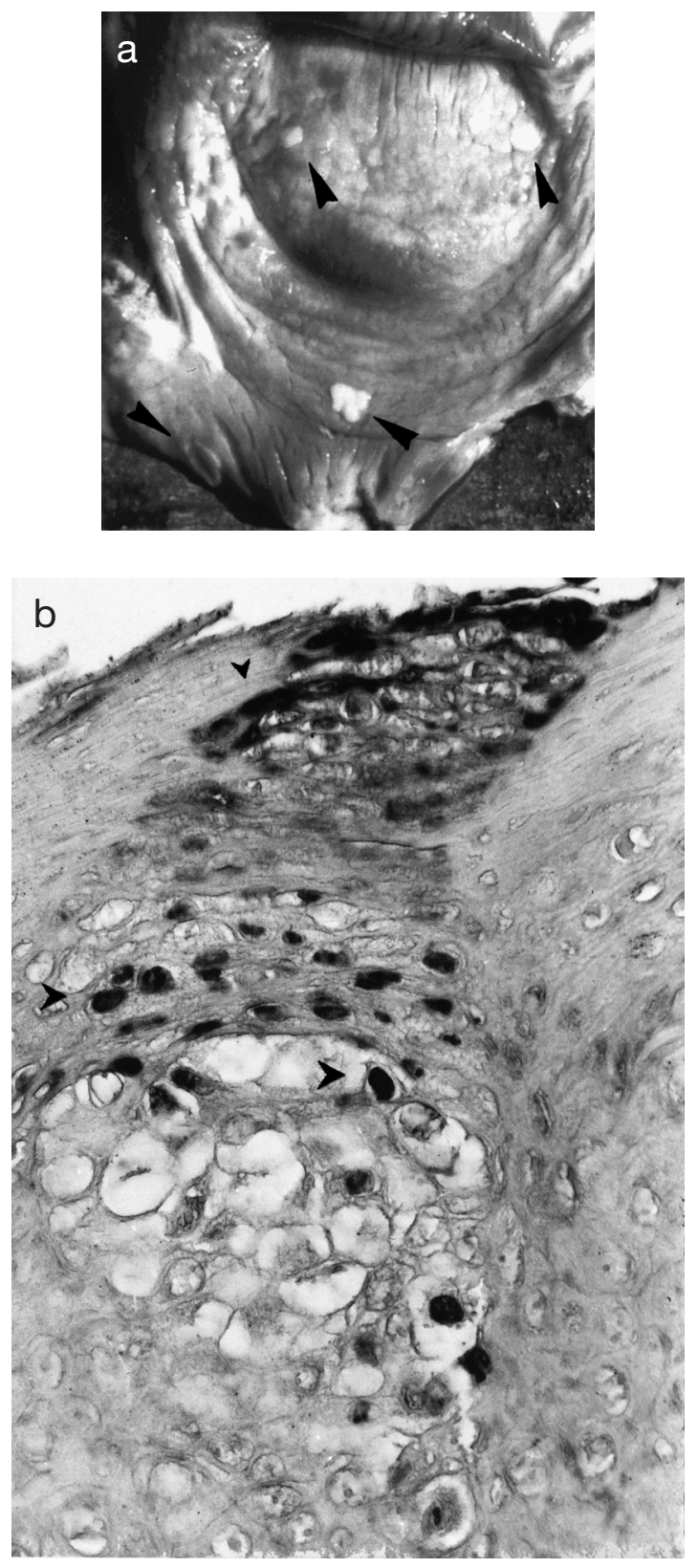

Fig. 2. Phocoena spinipinnis. (a) Whitish-coloured warts in the vagina of porpoise JAS-50 (arrowheads). (b) Detection of group-specific papillomavirus antigen in superficial keratinocytes of a genital wart from porpoise JAS-44 using a polyclonal rabbit immune serum against disrupted particles of human papillomavirus type 1 (HPV-1). Nuclear staining (arrowheads) is visible in a cluster of differentiating cells and in adjacent, more superficially differentiated cells $($ magnification $\times 350$ ) 
the detection of PV sequences in 5 of the 7 genital warts examined indicated that PV infection is very frequent in this population. Though PVs are ubiquitous and commonly found on the skin and mucosae of the genital tract of humans and other animal species, clinical disease only develops in a small minority of them and it is believed that additional factors (immune status, genetic predispositions, nutritional status, environmental factors) are involved in the process of tumour development (Mougin et al. 2001, Antonsson \& Hansson 2002). The high prevalence of genital papillomas in $P$. spinipinnis may point to immune depression in this population. This would be consistent with results of a recent epidemiological study covering 17 cetacean species where the highest prevalence of poxvirusassociated tattoo skin disease (TSD) was also encountered in Peruvian P. spinipinnis (Van Bressem et al. 2009a). The significantly higher prevalence of genital warts in male $P$. spinipinnis may reflect the accumulation of immunosuppressive lipophilic contaminants through life in adult males and the depuration of females through transfer of their contaminant loads to their calves (Jepson et al. 2005, Wells et al. 2005). Chronic stress from intense fishery interactions may also play a role in the development of papillomas in cetaceans by depressing the immune system and acting synergistically with immunosuppressive contaminants (Clark et al. 2006, Hall et al. 2006, Martineau 2007).

Phocoena spinipinnis may become infected early in life through vertical and horizontal transmission (Van Bressem et al. 1996, 2007a). Genital warts of sufficient severity that may impede, or at least hamper, copulation affected 2 of 20 male $P$. spinipinnis examined but were not seen in other Peruvian small cetaceans. A sperm whale has also been reported to suffer extensive genital papillomatosis (Lambertsen et al. 1987). PVs in some circumstances (especially if non-randomly distributed) may exert an indirect impact on population dynamics (Lambertsen et al. 1987, Van Bressem et al. 1999).

As in other mammals (Howley \& Lowy 2001) cetacean papillomaviruses appear to be speciesspecific (Van Bressem et al. 2007a, Rector et al. 2008). However, as recombination can occur between the Papillomaviridae leading to viable recombinants (Varsani et al. 2006, Rector et al. 2008), precaution is recommended when sampling genital warts in live cetaceans or fresh carcasses.

\section{Cetacean poxviruses and TSD}

TSD is characterised by very typical, irregular, grey, black or yellowish, stippled cutaneous lesions referred to as tattoos that may occur on any body part but show a preferential corporal distribution depending on the species (Fig. 3). Individual tattoo lesions may persist for months or years and recurrence is possible (Van Bressem \& Van Waerebeek 1996, Van Bressem et al. 2003). TSD has been reported in 17 free-ranging species, including Delphinidae $(\mathrm{n}=13)$, Phocoenidae $(\mathrm{n}=$ $2)$, Ziphiidae $(n=1)$ and Balaenidae $(n=1)$, as well as in captive Tursiops truncatus and Indo-Pacific bottlenose dolphins Tursiops aduncus (Van Bressem et al. 1999, 2007b, 2009a, Bracht et al. 2006). It is caused by poxviruses that may belong to a new genus of the subfamily Chordopoxvirinae (family Chordopoxviridae), but have a common, most immediate ancestor with terrestrial poxviruses of the genus Orthopoxvirus (Bracht

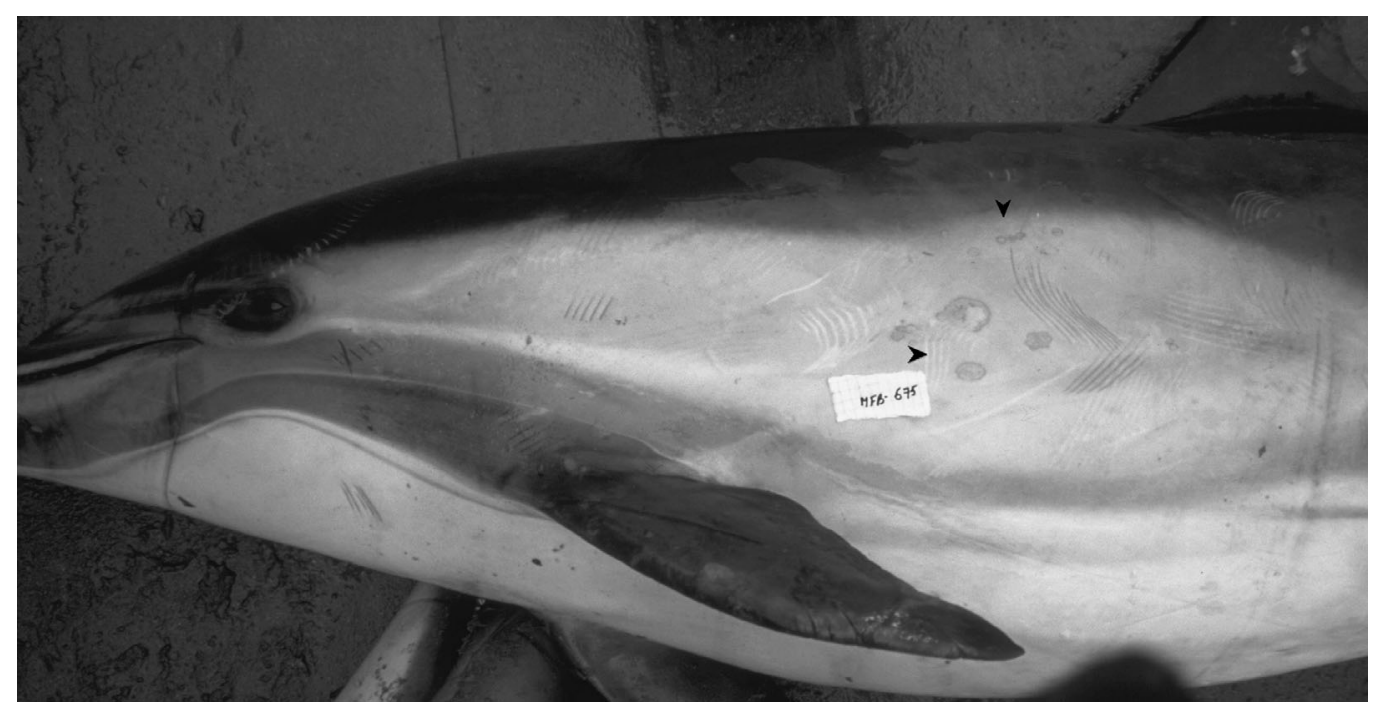

Fig. 3. Delphinus capensis. Tattoo lesions (arrowheads) on the left flank of long-beaked common dolphin MFB-675 caught off central Peru in 1994 
et al. 2006). TSD poxviruses are thought to induce humoral immunity protecting neonates and young calves (Smith et al. 1983, Van Bressem \& Van Waerebeek 1996). A recent study in 17 cetacean species (1392 individuals) from 3 oceans and contiguous seas showed a common pattern for endemic TSD: a significant increase in prevalence in juveniles compared to calves, presumably due to juveniles that had lost maternal humoral immunity, as well as a significantly higher prevalence in juveniles than in adults, possibly because a high percentage of adults had acquired active immunity following infection. This epidemiological pattern was found inverted in samples of poor health odontocetes, possibly the result of a depressed immune system (Van Bressem et al. 2009a).

When endemic, TSD does not appear to induce a high mortality rate (Van Bressem \& Van Waerebeek 1996, Van Bressem et al. 2003). However, it may kill neonates and calves without protective immunity and thus could interfere with host population dynamics (Van Bressem et al. 1999). A severe, generalized poxvirus infection, as apparent from a large number of disseminated tattoos in a calf Sotalia guianensis that live-stranded on the coast of Pará state, Brazil, in March 2008 (S. Siciliano pers. obs.) lends weight to this hypothesis. Super-infection by fungi or bacteria may exacerbate TSD and contribute to mortalities (Smith et al. 1983, Van Bressem et al. 2003, 2007b). The role of environmental factors in the course, severity and epidemiology of the disease is unknown. We hypothesize that immunosuppressive contaminants and severe, chronic stress levels among sociable cetaceans in areas with persistently elevated mortality rates from bycatch may contribute to higher prevalences of TSD in adults, cases of progressive TSD as evidenced by very large tattoo lesions, as well as to recurrence.

Although TSD poxviruses seem to be cetaceanspecific (Bracht et al. 2006, Pearce et al. 2008) and no transmission to humans has been reported, it is recommended that persons (especially if immuno-compromised) who handle live cetaceans or fresh carcasses with tattoo lesions use gloves. Further research should include serological tests in conjunction with examination of tattoo lesions by electron microscopy and molecular techniques.

\section{BRUCELLOSIS}

Brucellosis is a globally distributed zoonotic disease of mammals that is pathogenic for the reticuloendothelial, reproductive, musculoskeletal and cutaneous systems and may cause generalized infection with septicaemia in humans (Corbel 1997). The aetiologic agent is a Gram-negative, facultative intracellu- lar bacterium of the genus Brucella. From the 1990s onward, previously unknown strains of Brucella were detected in free-ranging pinnipeds and cetaceans from the Americas, Europe, Japan, New Zealand, the Solomon Islands and the Antarctic as well as in captive Tursiops truncatus (Ewalt et al. 1994, Ross et al. 1994, Ohishi et al. 2003, Duignan et al. 2005, Tachibana et al. 2006, Hernández-Mora et al. 2008). Phylogenetic analyses show that the marine Brucella isolates form a new group that originates very near the $B$. ovis branch and that the seal, porpoise and dolphin strains diverged a very long time ago, concurrent with the evolution of their hosts (Bourg et al. 2007). On the basis of biological and molecular characteristics, Foster et al. (2007) proposed 2 Brucella species in marine mammals, B. ceti and B. pinnipedialis with, respectively, cetaceans and seals as preferred hosts. Groussaud et al. (2007) further suggested that brucellae isolated from cetaceans constitute 2 species with different preferred hosts, i.e. B. phocoenae in porpoises and B. delphini in dolphins.

Pathogenic findings associated with brucellosis in cetaceans include placentitis, orchitis, abortion, mastitis, pneumonia, subcutaneous lesions, arthritis, nonsuppurative meningo-encephalitis and encephalitis, hepatic and splenic coagulative necrosis and lymphadenitis (Miller et al. 1999, Foster et al. 2002, Gonzáles et al. 2002, Ohishi et al. 2003, Dagleish et al. 2007, 2008, Hernández-Mora et al. 2008, Davison et al. 2009). Brucella-induced neurologic disorders may lead to strandings (Hernández-Mora et al. 2008, Davison et al. 2009). Marine brucellae were detected by PCR amplification and DNA sequencing of granular lesions with caseation and calcification affecting the testes in $33.3 \%$ of 39 common minke whales Balaenoptera acutorostrata taken by Japanese whalers in the North Pacific in 2000 to 2001 (Ohishi et al. 2003, 2004). Brucella spp. strains, including $B$. ceti, were also isolated from the placenta and fetal tissues of captive Tursiops truncatus and in stranded Stenella coeruleoalba (Pacific coast of Costa Rica) as well as from a testicular abscess in a sexually mature Phocoena phocoena (Atlantic coast of the UK) (Miller et al. 1999, Dagleish et al. 2008, Hernández-Mora et al. 2008).

Brucellosis is endemic in several species and populations worldwide and, in Peruvian small cetaceans, affects significantly more sexually mature than immature individuals (Van Bressem et al. 2001b). Brucella ceti infection may measurably limit recruitment by compromising the normal functioning of male and female reproductive systems, inducing abortions and by killing neonates and sexually mature individuals. This could have significant consequences for endangered cetaceans such as Hector's dolphins Cephalorhynchus hectori hectori and Maui's dolphins C. hec- 
tori maui (Duignan et al. 2005). Marine brucellae may be transmitted horizontally and vertically. Dawson et al. (2008) suggested that the lungworm Pseudalius inflexus may be a reservoir and vector for the bacteria in $P$. phocoena from the British Isles.

To date there are 4 known cases of humans infected with Brucella spp. from marine mammals, 3 naturally acquired and 1 of laboratory origin (Brew et al. 1999, Sohn et al. 2003, McDonald et al. 2006). The laboratory case was mild and caused by sequence type (ST) 23, a genotype mostly associated with North Atlantic Phocoena phocoena (Whatmore et al. 2008). The naturally acquired cases occurred in 2 patients from Peru and 1 from New Zealand who had eaten raw fish and unpasteurized cheese but did not recall contact with marine mammals (Sohn et al. 2003, McDonald et al. 2006). Human disease was triggered by closely related organisms that represent an identical genotype (ST27) shared with the F5/99 strain isolated from an aborted Tursiops truncatus foetus (California, USA) and circulating in B. acutorostrata from the North Pacific (Whatmore et al. 2008). The naturally infected humans were seriously ill with neurobrucellosis, intracerebral granulomas and spinal osteomyelitis. It is possible that members of the ST27 genotype have an increased zoonotic potential and are more pathogenic to humans (Whatmore et al. 2008).

Prevalence of human brucellosis from cetacean origin may be significantly underestimated in developing countries in Africa, South America and SE Asia, where freshly dead cetaceans are frequently handled, butchered and used as 'marine bushmeat' for human consumption or as bait in artisanal fisheries (e.g. Van Waerebeek et al. 1997, Ofori-Danson et al. 2003, Clapham \& Van Waerebeek 2007, Alfaro-Shigueto et al. 2008) without any hygienic precautions. One of the authors (K. Van Waerebeek) suffered an undiagnosed but debilitating chronic disease in 1990 to 1992, a period when he necropsied hundreds of freshly dead small cetaceans in Peruvian fish markets (see Van Waerebeek \& Reyes 1994) without gloves or protective clothing. Clinical manifestations were severe, systemic and, in retrospect, consistent with brucellosis (Corbel 1997), including seizures with loss of consciousness, severe myalgias and back aches, undulating fever, profuse night sweats, cephalgias, persistent chronic fatigue, anorexia and dramatic weight loss (>10\%). Contemporaneously, a middle-aged female fishmonger at the Pucusana port in central Peru who specialized in the trade of small cetaceans for human consumption, queried about her progressive weight loss, admitted to grossly identical clinical symptoms (K. Van Waerebeek pers. obs.). Despite numerous medical consultations and standard hematologic, parasitologic and serological tests for common diseases in Peru, no diagnosis was made for either patient. Generalized symptoms and prolonged illness have also been reported in several marine mammal workers during a global survey. Though most cases were not further diagnosed, brucellosis was suspected in at least 2 workers (Hunt et al. 2008). Restrictions should be applied to programmes where tourists are allowed to swim and interact closely with captive dolphins when Brucella spp. could be circulating in these colonies. Dolphins should at least be screened serologically for Brucella spp. before they are used for such purposes.

The role of environmental factors in the emergence of marine mammal brucellosis is unknown.

\section{TOXOPLASMOSIS}

Toxoplasma gondii is an obligate intracellular protozoan parasite belonging to the Apicomplexa phylum that causes toxoplasmosis in human and other warmblooded animals worldwide including cetaceans (Dubey et al. 2003). Wild and domestic felids are the only animals known to serve as definitive hosts for $T$. gondii genotypes I through III, but many mammals can be intermediate hosts (Miller et al. 2008). Infection occurs through the ingestion of contaminated food or water, or transplacentally. In cetaceans, toxoplasmosis was first reported in a Sotalia guianensis from Brazil (Bandoli \& de Oliveira 1977). Infected free-ranging odontocetes have been reported in Europe, the Americas and the Caribbean. They presented lymphadenitis, necrotizing adrenal adenitis, myocarditis, acute interstitial pneumonia, non-suppurative encephalitis (Fig. 4) and systemic disease. Transplacental fetal infection was reported in a free-ranging Risso's dolphin Grampus griseus and a captive Tursiops aduncus (reviewed in Dubey et al. 2003). Toxoplasmosis was often, though not always, associated with immunosuppression following a morbillivirus infection and/or high concentrations of environmental contaminants including PCBs (Di Guardo et al. 1995, Mikaelian et al. 2000).

Toxoplasma gondii is the sole recognized species in the genus and, until recently, was composed of 3 major genotypes designed as Types I through III that have emerged as dominant strains worldwide (Conrad et al. 2005). Two new clades of T. gondii, named Type A and Type X, were recently detected in a Pacific harbour seal Phoca vitulina richardsi, a California sea lion Zalophus californianus, southern sea otters Enhydra lutris nereis and northern sea otters E. lutris kenyoni from California and Washington State, as well as in a California mussel Mytilus californianus, the wild coastal felids Lynx rufus and Puma concolor, and a red fox Vulpes vulpes dwelling near Monterey and Estero 


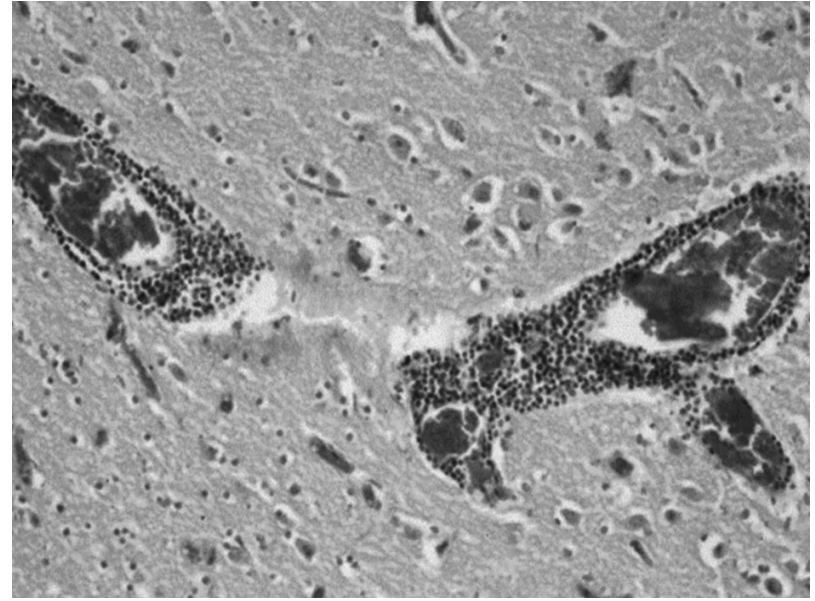

Fig. 4. Stenella coeruleoalba. Non-suppurative encephalitis in a dolphin stranded on the coast of Tuscany, Italy, in 1993, that was concurrently infected by dolphin morbillivirus and Toxoplasma gondii. Prominent cuffs of inflammatory mononuclear cells are present around the blood vessels of the sub-cortical grey matter. Haematoxylin and eosin staining (magnification $\times 125$ )

Bays, California. These observations suggest that feline fecal contamination is flowing from land to sea through surface run-off and that sea otters may be infected through the consumption of infected marine invertebrates (Conrad et al. 2005, Miller et al. 2008, Johnson et al. 2009).

We believe that the infection of offshore species like Grampus griseus and Stenella coeruleoalba could be linked to ship run-off waters when hygienic conditions are poor and when rodents, cats or contaminated soil are present onboard. Waterborne transmission of Toxoplasma gondii may be much more common than previously thought (Jones \& Dubey 2009) and the global maritime trade is thought to be responsible for the dissemination of T. gondii from its original niche in South America to other continents (Lehmann et al. 2006). Degradation of the marine environment and food reduction may also play a role in the emergence of toxoplasmosis in marine mammals. A recent study in Enhydra lutris nereis from California suggests that high levels of $T$. gondii infection may be an adverse consequence of dietary specialization related to a resource-limited coastal system (Johnson et al. 2009).

Though the potential of Toxoplasma gondii to affect cetacean populations has not yet been investigated, its ability to cause lethal systemic diseases and abortions renders it highly suspect. T. gondii may contribute to the slow recovery rate of the southern sea otter population (Conrad et al. 2005). Besides, the possible reactivation of latent $T$. gondii infection during morbillivirus outbreaks may synergistically increase the severity and death rate of this viral disease. High levels of coinfection with the hemoprotozoan parasite Babesia spp. increased the severity of canine distemper virus epidemics in African lions Panthera leo (Munson et al. 2008).

Toxoplasmosis is zoonotic globally. Humans become infected with Toxoplasma gondii mainly by ingesting uncooked meat containing viable tissue cysts or by ingesting food or water contaminated with oocysts from the feces of infected Felidae (Jones \& Dubey 2009). The consumption of raw or incompletely cooked cetacean meat, customary in some countries (Muckle et al. 2001, Clapham \& Van Waerebeek 2007), likely represents an incompletely assessed health hazard. Marine mammals may serve as sentinels of protozoan pathogen pollution.

\section{LOBOMYCOSIS}

Lobomycosis ${ }^{1}$ (lacaziosis) is caused by the yeast-like organism Lacazia loboi (Taborda et al. 1999) (syn. Loboa loboi; Caldwell et al. 1975). It is an uncultivated pathogen that belongs with the other dimorphic fungi to the order Onygenales, family Ajellomycetaceae (Herr et al. 2001, Vilela et al. 2009). L. loboi naturally affects Tursiops truncatus and Sotalia guianensis from the Americas as well as humans (Caldwell et al. 1975, Symmers 1983, Paniz-Mondolfi et al. 2007, Van Bressem et al. 2007b). L. loboi cells found in infected tissues from T. truncatus are significantly smaller than those found in humans, which, according to Haubold et al. (2000), suggests that the organism may not be identical in the 2 hosts. However, serological data indicate that dolphins and humans are infected with similar L. loboi strains (Mendoza et al. 2008). In humans, lobomycosis is a chronic fungal infection of the skin, endemic in rural regions in South and Central America. Water, earth and vegetation are considered ecological habitats of the fungus that may access the skin by penetration or accidental trauma (Paniz-Mondolfi et al. 2007). Patients with lobomycosis may suffer immunoregulatory disturbances that may be responsible for the lack of pathogen containment (VilaniMoreno et al. 2004).

Lobomycosis in Delphinidae is characterized by greyish, whitish to slightly pink, verrucous lesions, often in pronounced relief (Fig. 5), that may ulcerate

\footnotetext{
1The disease's nomenclature of lobomycosis (or Lobo's disease) is a recommended nomen conservandum by virtue of its common usage since at least 1973 and the fact that it honours its discoverer, Jorge Lobo, who in 1931 described the first case of a chronic, cutaneous mycosis in man, which he then called keloidal blastomycosis
} 


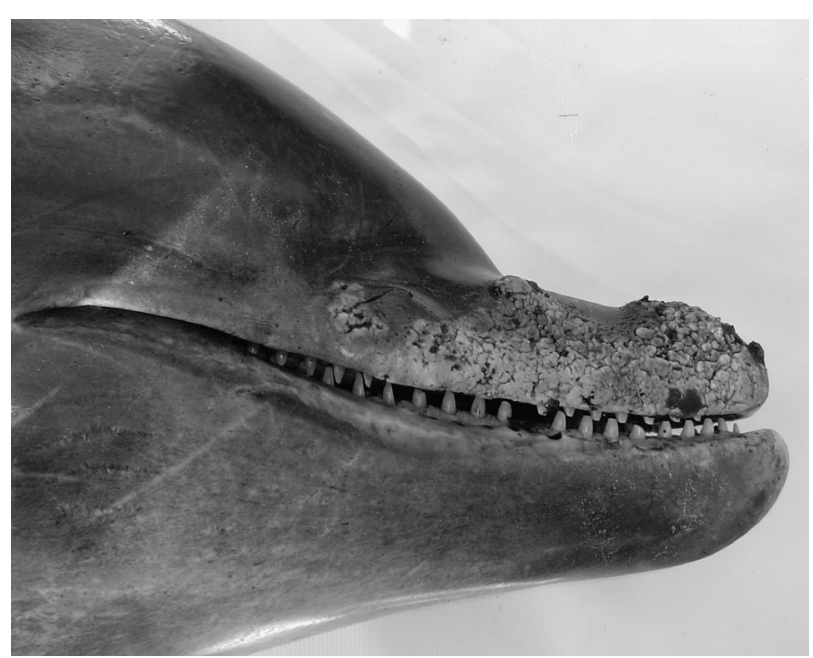

Fig. 5. Tursiops truncatus. Extensive lobomycosis characterized by raised, greyish, verrucous lesions, sometimes ulcerated, on the beak of a male dolphin from the Tramandaí estuary, Brazil, found dead in November 2005

and form plaques that may exceed $30 \mathrm{~cm}$ in their broadest dimension (Reif et al. 2008). Initially only observed in inshore/estuarine Tursiops truncatus and Sotalia guianensis, lobomycosis was recently detected in offshore $T$. truncatus off northern California, suggesting that its range may be expanding (Rotstein et al. 2009) or that its offshore occurrence has eluded scientists to date. Dolphins may live with this progressive disease for several years (Murdoch et al. 2008). However, their general condition may deteriorate markedly as the disease advances, with death following. Whether this is due to $L$. loboi infection or to other causes is still uncertain (Symmers 1983). A review of the literature (Migaki et al. 1971, Caldwell et al. 1975, Bossart 1984, Simões-Lopes et al. 1993, Bossart et al. 2003, Moreno et al. 2008, Rotstein et al. 2009) revealed that at least $11 \mathrm{~T}$. truncatus (9 inshore, 2 offshore) died with advanced lobomycosis in North and South America. Besides the presence of L. loboi in the axillary lymph nodes of one specimen, none of the 5 dolphins investigated in detail had involvement of internal organs or mucous membranes. The disease is endemic in T. truncatus from the Indian River Lagoon, Florida, with prevalence levels oscillating between $6 \%$ (n = $484)$ and $12.4 \%(n=186)$ in the period 1996 to 2006 (Murdoch et al. 2008). Affected dolphins from this region have significant impairment in adaptive immunity, possibly related to chronic exposure to environmental stressors (Reif et al. 2008).

In South America and the SW Indian Ocean, several cases highly reminiscent of lobomycosis were observed in free-ranging inshore Tursiops truncatus, $T$. aduncus and Sotalia guianensis. In the absence of a histological diagnosis, the disease was called lobomycosis-like disease (LLD) (Van Bressem et al. 2007b, 2009b, Kiszka et al. 2009). As in the case of lobomycosis, LLD evolves over years and is associated with the death or disappearance of severely affected dolphins. Two T. truncatus stranded dead with generalized LLD in Brazil and Venezuela in 2003 and 2004, while 2 other well-known individuals with severe LLD disappeared in 2003 (Moreno et al. 2008). A severely affected calf from Mayotte Lagoon also disappeared in early 2006 (Kiszka et al. 2009). Prevalence of LLD in inshore South American T. truncatus varied from 1.6\% (Gulf of Guayaquil, Ecuador) to $20 \%$ (Tramandaí estuary, Brazil) (Van Bressem et al. 2007b, Moreno et al. 2008). Along the Atlantic coast of South America, lobomycosis was first observed in an adult female $S$. guianensis caught in the estuary of the Surinam River in 1971 and subsequently in an adult female T. truncatus stranded in Santa Catarina State, southern Brazil, in 1990 (de Vries \& Laarman 1973, Simões-Lopes et al. 1993). Though no other cases were reported until recently (Van Bressem et al. 2007b), a retrospective study in southern Brazil provided evidence that cutaneous mycosis, including lobomycosis and LLD, affected T. truncatus in Rio Grande do Sul State (south of Santa Catarina) from at least 1995 to 2008 (Moreno et al. 2008). LLD was also observed in 2 T. truncatus from Baía Norte and in 4 of 103 S. guianensis inhabiting the Paranaguá estuary in 2003 to 2007 (Van Bressem et al. 2007b, 2009b). Thus, lobomycosis and LLD in Brazilian Delphinidae seem to be concentrated in southern Brazil, from $25^{\circ} 22^{\prime} \mathrm{S}, 48^{\circ} 25^{\prime} \mathrm{W}$ to $31^{\circ} 17^{\prime} \mathrm{S}, 50^{\circ} 57^{\prime} \mathrm{W}$ (Moreno et al. 2008, Van Bressem et al. 2009b). A single case of LLD occurred in 2004 in a T. truncatus from Margarita Island, Venezuelan Caribbean, where lobomycosis or LLD had never before been encountered in humans nor dolphins (Bermudez et al. 2009). On the Pacific coast of South America, the first described cases of LLD date back to 1991, in an inshore T. truncatus community from the Estuary of Guayaquil, Ecuador (Van Bressem et al. 2007b). Further cases of LLD were reported in $2 T$. truncatus from Bahía Malaga, Colombia, and in $1 \mathrm{~T}$. truncatus from central Peru in 2005 and 2006 (Van Bressem et al. 2007b). The disease has also been present in $T$. aduncus in the Mozambique Channel at Mayotte since at least 1999, with a prevalence of $8.4 \%$ in 71 adults for the period 2004 to 2008 (Kiszka et al. 2009).

Though initially described only in large, presumably adult dolphins, LLD has recently also been seen in 2 calves, a Sotalia guianensis from the Paranaguá estuary and a Tursiops aduncus from Mayottte. This latter specimen was extensively affected and disappeared (Van Bressem et al. 2009b, Kiszka et al. 2009). The impact of lobomycosis and LLD on cetacean popula- 
tions is unknown but the disease may have contributed to the death of several specimens.

A unique case of transmission of lobomycosis from Tursiops truncatus to a human was reported in Europe in the early 1970s (Symmers 1983). Norton (2006) believed that the transmission rate of lobomycosis from animals to humans is very low. Recently, a second case of zoonotic transmission was reported in a laboratory worker who most likely acquired lobomycosis after manipulating experimentally infected mice (Rosa et al. 2009). As for brucellosis, additional cases may remain undiagnosed in South and Central American countries. Close contact with infected dolphins may be risky and precautionary restrictions should apply with regard to programmes that allow thousands of tourists of unknown immunological status to swim with dolphins (Samuels \& Spradling 1995). Till recently, the distribution and epidemiology of lobomycosis in humans and dontocetes seemed to be unconnected, affecting mostly humans inhabiting the Amazon basin and inshore and estuarine dolphins from the tropical and subtropical western Atlantic coast (Van Bressem et al. 2007b, Reif et al. 2008). However, recent findings suggest that humans may contract lobomycosis from the marine environment in South America (Bermudez et al. 2009).

The factors driving the apparent emergence of lobomycosis and LLD in South America and Mayotte are unknown. Several of the affected populations inhabit biologically and chemically polluted waters around major ports and cities and, in the case of Guayaquil, waters harbouring intense shrimp farming (Van Bressem et al. 2007b, 2009b, Kiszka et al. 2009). The role of increased shipping in introducing Lacazia loboi to new ecological niches must be explored. The discharge of water, sediments and biofilms from ships' ballast water tanks is a prominent known vector of aquatic invasive species (Ruiz et al. 2000, Drake et al. 2007). Global warming may also play a role as it expands the tropical belt (Seidel et al. 2008) and hence, possibly, the range of lobomycosis. Global warming-driven ecological modifications may affect local soil ecology and hydrology, resulting in the persistence of invasive fungal pathogens and release of infectious spores (Greer et al. 2008). Variation in salinity and water temperature are other parameters to consider in L. loboi infection (Reif et al. 2006).

\section{DISEASES OF MULTIFACTORIAL AETIOLOGY}

Recent studies have demonstrated a significant association between both chronic PCB and trace metal exposure and infectious diseases (including parasitic, bacterial and mycotic pneumonia and generalized bacterial infections) in Phocoena phocoena from the North and Baltic Seas (Siebert et al. 1999, Bennett et al. 2001, Jepson et al. 2005, Hall et al. 2006). P. phocoena from the British Isles that died in poor health had a significantly higher sum of the concentrations of 25 individual chlorobiphenyl congeners ( $\Sigma 25 \mathrm{CBs})$ than those that perished by traumatic death. Adult females in both groups had significantly lower $\Sigma 25 \mathrm{CBs}$ levels than adult males because of off-loading of organochlorines during gestation and lactation (Jepson et al. 2005). Pollutants also negatively affected the immune and endocrinal systems of $P$. phocoena in these waters (Beineke et al. 2005, Das et al. 2006), but much remains to be learned about the full impact on these populations.

\section{CONCLUSIONS}

Cetaceans are infected by a wide variety of pathogens that may be order-, family- or species-specific (e.g. morbilli-, pox- and papillomaviruses) or opportunistic (bacteria, fungi, protozoa). Infections by specific pathogens are likely to have occurred for thousands of years with some equilibrium between populations and pathogens as in other species (Begon et al. 1996). Environmental degradation, including biological and chemical pollution, climate change, fisheries, noise and heavy boat traffic, is thought to have disturbed this equilibrium by lowering the population immune response, depressing food supplies, increasing stress and facilitating the introduction of alien pathogens, among others (Fair \& Becker 2000, Bossart 2007, Burek et al. 2008, Miller et al. 2008, Reif et al. 2008, Johnson et al. 2009). The reported number and severity of cetacean diseases have increased, in part because of more dedicated research in this field (Gulland \& Hall 2007). However, taking this bias into account, some morbidity rates seem to have accrued, such as, for example, those resulting from exposure to harmful algal blooms (HABs), morbillivirus outbreaks in the North Atlantic and contiguous seas and LLD cases in South American cetaceans (Gulland \& Hall 2007, Van Bressem et al. 2007b, Raga et al. 2008). Trend analysis for poorly studied or recently recognized diseases is often hampered by the lack of adequate quantitative data of long-term (background) prevalence levels, even though observed present-day prevalence may seem alarmingly high.

There is mounting circumstantial evidence that chemical pollution has increased the emergence and severity of several diseases in pinnipeds and cetaceans (Aguilar \& Borrell 1994, Ross et al. 2000, Ross 2002, Jepson et al. 2005, Hall et al. 2006). Biological pollution is an emerging issue, with the findings of terrestrial pathogens in marine mammals, of a significant increased fecal coliform count in harbour seals living 
near urban developments and of cutaneous disorders of miscelleanous aetiology in coastal odontocetes (Mos et al. 2006, Van Bressem et al. 2007b, Miller et al. 2008). Climate changes can increase water temperatures, modify the distribution of vectors and reservoir species, change pathogen and host interaction dynamics and alter pathogen transmission cycles (Greer et al. 2008). Such changes have facilitated the establishment, emergence or possible resurgence of Cryptococcus gattii in Canada and promoted a multi-species outbreak (including the Dall's porpoise Phocoenoides dalli and Phocoena phocoena) (Kidd et al. 2004). Climate changes have also affected the geographical distribution of arthropod-borne viruses (arboviruses) (Gould \& Higgs 2008). Whether these viruses may emerge in cetaceans is currently unknown. However, St. Louis encephalitis virus (arboviruses Family Flaviviridae, genus Flavivirus) has caused the death of a captive killer whale Orcinus orca (Buck et al. 1993). The louse Lepidophthirus macrorhini is likely the reservoir and vector of the Southern elephant seal alphavirus (Family Togoviridae, genus Alphavirus; La Linn et al. 2001). Whether marine arthropods like Cyamidae (whale lice), parasitic on cetaceans, carry arboviruses remains to be investigated. Marine birds, especially gulls Larus spp. may serve as vector and reservoir of pathogens such as influenza viruses (Ohishi et al. 2006) and Escherichia coli (Nelson et al. 2008).

Brucella spp. and other bacteria (i.e. Mycobacterium spp. and Erysipelothrix rhusiopathiae), St. Louis encephalitis virus, Lacazia loboi and Toxoplasma gondii are zoonotic pathogens (Flowers 1970, Chastel et al. 1975, Kuno \& Chang 2005). Standard sanitary precautions are recommended during physical contact with live cetaceans, and especially with stranded or other individuals exhibiting clinical signs of infectious pathologies. When handling fresh cetacean products such as blood, tissues, biopsy samples, muscle (meat) and skin (blubber), the systematic use of gloves and protective clothing would be optimal. However, it is clear that in field conditions and communal or aboriginal environments such preventative measures may be unrealistic, especially in developing countries. In humans, an estimated $75 \%$ of emerging diseases are zoonotic, with wildlife representing a large and mostly unknown reservoir (Cunningham 2005). Consumption of bushmeat (including cetacean meat), development of ecotourism and access to petting zoos favour the transmission of zoonotic diseases. Unidentified longlasting or recurrent illnesses in humans working with dolphins or handling cetacean carcasses have recently been described (Hunt et al. 2008; this paper).

We conclude that anthropogenic environmental changes may increase the prevalence and severity of infectious illnesses in dolphins, porpoises and whales worldwide. Inshore, estuarine and riverine cetaceans seem particularly at risk because coastal and fluvial ecosystems are often dramatically degraded by human activities, are more heavily polluted both biologically and chemically, and are most prone to the effects of climate change. Neritic and fluvial species are also more likely killed, injured, disturbed or stressed by frequent, direct and indirect fisheries interactions, and by collisions with vessels (Van Waerebeek et al. 2007). A high prevalence of traumatic injuries, even minor skin lacerations, in concert with a compromised immune system create ideal targets for opportunistic pathogens.

Acknowledgements. M.F.V.B. received funding from the Whale and Dolphin Conservation Society (WDCS) and the Cetacean Society International (CSI). CEPEC field research has benefited from long-term support by the International Fund for Animal Welfare (IFAW). The International Whaling Commission supported the attendance of M.F.V.B. to the IWC/60 Scientific Committee meeting in Santiago, Chile (June 2008), where an earlier draft of this manuscript was presented. K.V.W. served a contract for Belgium's Federal Public Service, Public Health, Food Chain Security and Environment, Brussels, Belgium. S.S. was supported by fellowships of the FIOCRUZ/FAPERJ and PROJETO PIATAM OCEANOCENPES/PETROBRAS, UFF, UFPA and MPEG. M.C.d.O.S. received a fellowship of the FAPESP and field grants from WDCS, CSI and Earthwatch Institute. I.B.M. was supported by a scholarship from CNPq and the GEMARS research was supported mainly by the Fundo Nacional do Meio Ambiente (FNMA), the Yacupacha Foundation and CSI. The Ministero dell'Ambiente e della Tutela del Territorio e del Mare, Roma, under the research project 'Cause di mortalità e studi patogenetici in cetacei spiaggiati sulle coste italiane' funded the work of G.D.G. Necropsies of cetaceans in the UK waters are funded under contract to the UK Government (Defra/Scottish Government/Welsh Assembly Government). We kindly thank Dr. G. Orth and P. Flamand (Institut Pasteur, Paris) for the image of the immunohistological characteristics of a genital wart from a Burmeister's porpoise. We are grateful to 4 anonymous reviewers for their useful comments on the manuscript.

\section{LITERATURE CITED}

Aguilar A (2000) Population biology, conservation threats, and status of Mediterranean striped dolphins (Stenella coeruleoalba). J Cet Res Manag 2:17-26

Aguilar A, Borrell A (1994) Abnormally high polychlorinated biphenyl levels in striped dolphins (Stenella coeruleoalba) affected by the 1990-1992 Mediterranean epizootic. Sci Total Environ 154:237-247

Aguilar A, Borrell A (2005) DDT and PCB reduction in the western Mediterranean in 1987-2002, as shown by levels in dolphins. Mar Environ Res 59:391-404

Aguilar A, Raga JA (1993) The striped dolphin epizootic in the Mediterranean Sea. Ambio 22:524-528

Alfaro-Shigueto JA, Mangel JC, Van Waerebeek K (2008) Small cetacean captures and CPUE estimates in artisanal fisheries operating from a port in northern Peru, 2005-2007. Paper SC/60/SM19 presented to IWC/60 Annual Meeting, Santiago, Chile, June 2008. (Available from IWC Secretariat, Cambridge) 
Antonsson A, Hansson BG (2002) Healthy skin of many animal species harbors papillomaviruses which are closely related to their human counterparts. J Virol 76:12537-12542

Aznar FJ, Perdiguero D, Pérez del Olmo A, Repullés A, Agustí C, Raga JA (2005) Changes in epizoic crustacean infestations during cetacean die-offs: the mass mortality of Mediterranean striped dolphins Stenella coeruleoalba revisited. Dis Aquat Org 67:239-247

Bandoli JG, de Oliveira CAB (1977) Toxoplasmose em Sotalia guianensis (Van Beneden, 1863), Cetacea, Delphinidae. Folha Med 75:459-468

Barrett T (1999) Morbillivirus infections, with special emphasis on morbilliviruses of carnivores. Vet Microbiol 69:3-13

Begon M, Harper JL, Townsend CR (1996) Ecology, 3rd edn. Blackwell Science, Oxford

Beineke A, Siebert U, Mac Lachlan M, Bruhn R and others (2005) Investigations of the potential influence of environmental contaminants on the thymus and spleen of harbor porpoises (Phocoena phocoena). Environ Sci Technol 39: 3933-3938

Bengis RG, Leighton FA, Fischer JR, Artois M, Mörner T, Tate CM (2004) The role of wildlife in emerging and re-emerging zoonoses. Rev Sci Tech Off Int Epiz 23:497-511

Bennett PM, Jepson PD, Law RJ, Jones BR and others (2001) Exposure to heavy metals and infectious disease mortality in harbour porpoises from England and Wales. Environ Pollut 112:33-40

Bermudez L, Van Bressem MF, Reyes-Jaimes O, Sayegh AJ, Paniz-Mondolfi A (2009) Lobomycosis and lobomycosislike disease in a fisherman and a common bottlenose dolphin (Tursiops truncatus) from the coast of Venezuela. Emerg Infect Dis 15:1301-1303

Bossart GD (2007) Emerging diseases in marine mammals: from dolphins to manatees. Microbes 2:544-549

Bossart GD, Meisner R, Varela R, Mazzoil M and others (2003) Pathologic findings in stranded Atlantic bottlenose dolphins (Tursiops truncatus) from the Indian River Lagoon, Florida. Fla Sci 66:226-238

- Bossart GD, Ghim SJ, Rehtanz M, Goldstein J and others (2005) Orogenital neoplasia in Atlantic bottlenose dolphins (Tursiops truncatus). Aquat Mamm 31:473-480

Bourg G, O'Callaghan D, Boschiroli ML (2007) The genomic structure of Brucella strains isolated from marine mammals gives clues to evolutionary history within the genus. Vet Microbiol 125:375-380

Bracht AJ, Brudek RL, Ewing RY, Manire CA and others (2006) Genetic identification of novel poxviruses of cetaceans and pinnipeds. Arch Virol 151:423-438

Brew SD, Perrett LL, Stack JA, Macmillan AP, Staunton NJ (1999) Human exposure to Brucella recovered from a sea mammal. Vet Rec 144:483

Buck C, Paulino GP, Medina DJ, Hsiung GD, Campbell TW, Walsh MT (1993) Isolation of St. Louis encephalitis virus from a killer whale. Clin Diagn Virol 1:109-112

Burek KA, Gulland FM, O'Hara TM (2008) Effects of climate change on Arctic marine mammal health. Ecol Appl 18(Suppl):S126-S134

Caldwell DK, Caldwell MC, Woodard JC, Ajello L, Kaplan W, McLure HM (1975) Lobomycosis as a disease of the Atlantic bottle-nosed dolphin (Tursiops truncatus Montagu, 1821). Am J Trop Med 24:105-114

Calzada N, Lockyer CH, Aguilar A (1994) Age and sex composition of the striped dolphin die-off in the western Mediterranean. Mar Mamm Sci 10:299-310

Cassonnet P, Van Bressem MF, Desaintes C, Van Waerebeek K, Orth G (1998) Papillomaviruses cause genital warts in small cetaceans from Peru. In: Evans PGH, Parsons ECM (eds) European research on cetaceans-12, Proc 12th ECS Conf, Monaco, 20-24 January 2004. European Cetacean Society, Monaco, p 349

- Chastel C, Masure O, Balouet G, Laban P, Lucas A (1975) The student, the cetacean and swine-fever: a minor epidemic after dissection of a globicephale. Nouv Presse Med 4: 1803-1805

Clapham P, Van Waerebeek K (2007) Bushmeat, the sum of the parts. Mol Ecol 16:2607-2609

Clark LS, Cowan DF, Pfeiffer DC (2006) Morphological changes in the Atlantic bottlenose dolphin (Tursiops truncatus) adrenal gland associated with chronic stress. J Comp Pathol 135:208-216

> Conrad PA, Miller MA, Kreuder C, James ER and others (2005) Transmission of Toxoplasma: clues from the study of sea otters as sentinels of Toxoplasma gondii flow into the marine environment. Int J Parasitol 35:1155-1168

Corbel MJ (1997) Brucellosis: an overview. Emerg Infect Dis 3:213-221

Cruz D, Guevara C, Blanco M, Sánchez L, Chamizo EG (2006) Papilomatosis en genitales de delfines (Tursiops truncatus) de zonas costeras del archipelago cubano. VI Congreso Internacional de Ciencias Veterinarias, La Habana, Cuba, 13 April 2006

Cunningham A (2005) A walk on the wild side-emerging wildlife diseases. BMJ 331:1214-1215

> Dagleish MP, Barley J, Howie FE, Reid RJ, Herman J, Foster G (2007) Isolation of Brucella species from a diseased atlanto-occipital joint of an Atlantic white-sided dolphin (Lagenorhynchus acutus). Vet Rec 160:876-878

> Dagleish MP, Barley J, Finlayson J, Reid RJ, Foster G (2008) Brucella ceti associated pathology in the testicle of a harbour porpoise (Phocoena phocoena). J Comp Pathol 139:54-59

> Das K, Vossen A, Tolley K, Vikingsson G and others (2006) Interfollicular fibrosis in the thyroid of the harbour porpoise: An endocrine disruption? Arch Environ Contam Toxicol 51:720-729

> Daszak P, Cunningham AA, Hyatt AD (2000) Emerging infectious diseases of wildlife-threats to biodiversity and human health. Science 287:443-449

> Daszak P, Cunningham AA, Hyatt A (2001) Anthropogenic environmental change and the emergence of infectious diseases in wildlife. Acta Trop 78:103-116

Datta K, Bartlett KH, Marr KA (2009) Cryptococcus gattii: emergence in Western North America: exploitation of a novel ecological niche. Interdiscip Perspect Infect Dis, doi: 10.1155/2009/176532

Davison NJ, Cranwell MP, Perrett LL, Dawson CE and others (2009) Meningoencephalitis associated with Brucella species in a live-stranded striped dolphin (Stenella coeruleoalba) in south-west England. Vet Rec 165:86-89

$>$ Dawson CE, Perrett LL, Stubberfield EJ, Stack JA and others (2008) Isolation and characterization of Brucella from the lungworms of a harbor porpoise (Phocoena phocoena). J Wildl Dis 44:237-246

de Vries GA, Laarman JJ (1973) A case of Lobo's disease in the dolphin Sotalia guianensis. Aquat Mamm 1:26-33

Di Guardo G, Agrimi U, Morelli L, Cardeti G, Terracciano G, Kennedy S (1995) Post mortem investigations on cetaceans found stranded on the coasts of Italy between 1990 and 1993. Vet Rec 136:439-442

> Domingo M, Ferrer L, Pumarola M, Marco A and others (1990) Morbillivirus in dolphins. Nature 348:21

> Drake L, Doblin MA, Dobbs FC (2007) Potential microbial bioinvasions via ships' ballast water, sediment, and biofilm. Mar Pollut Bull 55:333-341

Dubey JP, Zarnke R, Thomas NJ, Wong SK and others (2003) 
Toxoplasma gondii, Neospora caninum, Sarcocystis canislike infections in marine mammals. Vet Parasitol 116: 275-296

> Duignan PJ, Geraci JR, Raga JA, Calzada N (1992) Pathology of morbillivirus infection in striped dolphins (Stenella coeruleoalba) from Valencia and Murcia, Spain. Can J Vet Res 56:242-248

Duignan PJ, House C, Geraci JR, Early G and others (1995a) Morbillivirus infection in two species of pilot whales (Globicephala sp.) from the western Atlantic. Mar Mamm Sci 11:150-162

> Duignan PJ, House C, Geraci JR, Duffy N and others (1995b) Morbillivirus infection in cetaceans of the western Atlantic. Vet Microbiol 44:241-249

Duignan PJ, House C, Odell DK, Wells RS and others (1996) Morbillivirus infection in bottlenose dolphins: evidence for recurrent epizootics in the western Atlantic and Gulf of Mexico. Mar Mamm Sci 12:499-515

Duignan PJ, McDonald W, Mackereth G, Jamaluddin R and others (2005) Recent discovery of Brucella infection in New Zealand Hector's dolphins (Cephalorhynchus hectori hectori) - a potential cause of low fecundity and high perinatal mortality. Wildlife Disease Association International Conference, Cairns

Ewalt DR, Payeur JB, Martin BM, Cummins DR, Miller WG (1994) Characteristics of a Brucella species from a bottlenose dolphin (Tursiops truncatus). J Vet Diagn Invest 6:448-452

Fair PA, Becker PR (2000) Review of stress in marine mammals. J Aquat Ecosyst Stress Recovery 7:335-354

Fernández A, Esperón F, Herraéz P, Espinosa de los Monteros A and others (2008) Morbillivirus and pilot whale deaths, Mediterranean Sea. Emerg Infect Dis 14:792-794

Flowers DJ (1970) Human infection due to Mycobacterium marinum after a dolphin bite. J Clin Pathol 23:475-477

Forcada J, Aguilar A, Hammond PS, Pastor X, Aguilar R (1994) Distribution and numbers of striped dolphins in the western Mediterranean Sea after the 1990 epizootic outbreak. Mar Mamm Sci 10:137-150

Foster G, MacMillan AP, Godfroid J, Howie F and others (2002) A review of Brucella sp. infection of sea mammals with particular emphasis on isolates from Scotland. Vet Microbiol 90:563-580

Foster G, Osterman BS, Godfroid J, Jacques I, Cloeckaert A (2007) Brucella ceti sp. nov. and Brucella pinnipedialis sp. nov. for Brucella strains with cetaceans and seals as their preferred hosts. Int J Syst Evol Microbiol 57:2688-2693

Garibaldi F, Mignone W, Caroggio P, Ballardini M and others (2008) Serological evidence of Morbillivirus infection in striped dolphins (Stenella coeruleoalba) found stranded on the Ligurian Sea coast of Italy. In: Pierce GJ, Philips E, Lick R (eds) Proc 22nd ECS Conf, Egmond aan Zee, The Netherlands, 10-12 March 2008. European Cetacean Society, Egmond aan Zee, p 192-193

González L, Patterson IA, Reid RJ, Foster G and others (2002) Chronic meningoencephalitis associated with Brucella sp. infection in live-stranded striped dolphins Stenella coeruleoalba. J Comp Pathol 126:147-152

Gould EA, Higgs S (2008) Impact of climate change and other factors on emerging arbovirus diseases. Trans R Soc Trop Med Hyg 2008:15

> Greer A, Ng V, Fisman D (2008) Climate change and infectious diseases in North America: the road ahead. CMAJ 178:715-722

> Groussaud P, Shankster SJ, Koylass MS, Whatmore AM (2007) Molecular typing divides marine mammal strains of Brucella into at least three groups with distinct host preferences. J Med Microbiol 56:1512-1518
Gulland FM, Hall AJ (2007) Is marine mammal health deteriorating? Trends in the global reporting of marine mammal disease. EcoHealth 4:135-150

Hall A, Hugunin K, Deaville R, Law RJ, Allchin CR, Jepson P (2006) The risk of infection from polychlorinated biphenyl exposure in the harbor porpoise (Phocoena phocoena): a case-control approach. Environ Health Perspect 114: $704-711$

Haubold EM, Cooper CR Jr, Wen JW, Mcginnis MR, Cowan DF (2000) Comparative morphology of Lacazia loboi (syn. Loboa loboi) in dolphins and humans. Med Mycol 38:9-14

- Hernández-Mora G, González-Barrientos R, Morales JA, Chaves-Olarte E and others (2008) Neurobrucellosis in stranded dolphins, Costa Rica. Emerg Infect Dis 14: 1430-1433

> Herr RA, Tarcha EJ, Taborda PR, Taylor JW, Ajello L, Mendoza L (2001) Phylogenetic analysis of Lacazia loboi places this previously uncharacterized pathogen within the dimorphic Onygenales. J Clin Microbiol 39:309-314

Howley PM, Lowy DR (2001) Papillomaviruses and their replication. In: Knipe DM, Howley PM (eds) Fields virology, 4th edn, Vol 2. Lippincott Williams \& Wilkins, Philadelphia, PA, p 2197-2230

Hunt TD, Ziccardi MH, Gulland FM, Yochem PK, Hird DW, Rowles T, Mazet JA (2008) Health risks for marine mammal workers. Dis Aquat Org 81:81-92

Jepson PD, Bennett PM, Deaville R, Allchin CR, Baker JR, Law RJ (2005) Relationships between polychlorinated biphenyls and health status in harbor porpoises (Phocoena phocoena) stranded in the United Kingdom. Environ Toxicol Chem 24:238-248

> Johnson CK, Tinker MT, Estes JA, Conrad PA and others (2009) Prey choice and habitat use drive sea otter pathogen exposure in a resource-limited coastal system. Proc Natl Acad Sci USA 106:2242-2247

Jones JL, Dubey JP (2009) Waterborne toxoplasmosis recent developments. Exp Parasitol (in press) doi: 10.1016/j.exppara.2009.03.013

Kennedy S (1998) Morbillivirus infections in aquatic mammals. J Comp Pathol 119:201-225

> Kidd SE, Hagen F, Tscharke RL, Huynh M and others (2004) A rare genotype of Cryptococcus gattii caused the cryptococcosis outbreak on Vancouver Island (British Columbia, Canada). Proc Natl Acad Sci USA 101:17258-17263

> Kiszka J, Van Bressem MF, Pusineri C (2009) Lobomycosislike disease and other skin conditions in Indo-Pacific bottlenose dolphins Tursiops aduncus from the Indian Ocean. Dis Aquat Org 84:151-157

Kuno G, Chang GJ (2005) Biological transmission of arboviruses: reexamination of and new insights into components, mechanisms, and unique traits as well as their evolutionary trends. Clin Microbiol Rev 18:608-637

> La Linn M, Gardner J, Warrilow D, Darnell GA and others (2001) Arbovirus of marine mammals: a new alphavirus isolated from the elephant seal louse, Lepidophthirus macrorhini. J Virol 75:4103-4109

> Lambertsen RH, Kohn BA, Sundberg JP, Buergelt CD (1987) Genital papillomatosis in sperm whale bulls. J Wildl Dis 23:361-367

Lehmann T, Marcet PL, Graham DH, Dahl ER, Dubey JP (2006) Globalization and the population structure of Toxoplasma gondii. Proc Natl Acad Sci USA 103: 11423-11428

Lipscomb TP, Schulman FY, Moffett D, Kennedy S (1994) Morbilliviral disease in Atlantic bottlenose dolphins (Tursiops truncatus) from the 1987-1988 epizootic. J Wildl Dis 30:567-571 
Martineau D (2007) Potential synergism between stress and contaminants in free-ranging cetaceans. Int J Comp Psychol 20:194-216

McCullough SJ, McNeilly F, Allan GM, Kennedy S and others (1991) Isolation and characterisation of a porpoise morbillivirus. Arch Virol 118:247-252

> McDonald WL, Jamaludin R, Mackereth G, Hansen M and others (2006) Characterization of a Brucella sp. strain as a marine-mammal type despite isolation from a patient with spinal osteomyelitis in New Zealand. J Clin Microbiol 44: 4363-4370

McLellan W, Friedlaender A, Mead J, Potter C, Pabst DA (2002) Analysing 25 years of bottlenose dolphin (Tursiops truncatus) strandings along the Atlantic coast of the USA: Do historic records support the coastal migratory stock hypothesis. J Cet Res Manag 4:297-304

Mendoza L, Belone AF, Vilela R, Rehtanz M and others (2008) Use of sera from humans and dolphins with lacaziosis and sera from experimentally infected mice for Western Blot analyses of Lacazia loboi antigens. Clin Vaccine Immunol 15:164-167

Migaki G, Valerio MG, Irvine B, Garner FM (1971) Lobo's disease in an Atlantic bottle-nosed dolphin. J Am Vet Med Assoc 159:578-582

Mikaelian I, Boisclair J, Dubey JP, Kennedy S, Martineau D (2000) Toxoplasmosis in beluga whales (Delphinapterus leucas) from the St. Lawrence estuary: two cases reports and a serological survey. J Comp Pathol 122:73-76

Miller WG, Adams LG, Ficht TA, Cheville NF and others (1999) Brucella-induced abortions and infection in bottlenose dolphins (Tursiops truncatus). J Zoo Wildl Med 30:100-110

Miller MA, Miller WA, Conrad PA, James ER and others (2008) Type X Toxoplasma gondii in a wild mussel and terrestrial carnivores from coastal California: new linkages between terrestrial mammals, runoff and toxoplasmosis of sea otters. Int J Parasitol 38:1319-1328

Moreno IB, Ott PH, Tavares M, Oliveira LR and others (2008) Mycotic dermatitis in common bottlenose dolphins (Tursiops truncatus) from southern Brazil, with a confirmed record of lobomycosis disease. Paper SC/60/DW1 presented to the IWC Scientific Committee, Santiago, Chile, May 2008, Available at www.iwcoffice.org/_documents/ sci_com/SC60docs/SC-60-DW1(colour).pdf

Mos L, Morsey B, Jeffries SJ, Yunker MB, Raverty S, De Guise S, Ross PSR (2006) Chemical and biological pollution contribute to the immunological profiles of free-ranging harbour seals. Environ Toxicol Chem 25:3110-3117

> Mougin C, Dalstein V, Prétet JL, Gay C, Schaal JP, Riethmuller D (2001) Epidémiologie des infections cervicales à papillomavirus. Presse Med 30:1017-1023

Muckle G, Ayotte P, Dewailly E, Jacobson SW, Jacobson JL (2001) Determinants of polychlorinated biphenyls and methyl mercury exposure in Inuit women of childbearing age. Environ Health Perspect 109:957-963

Munson L, Terio KA, Kock R, Mlengeya T and others (2008) Climate extremes promote fatal co-infections during canine distemper epidemics in African lions. PLoS One 3: e2545

Murdoch ME, Reif JS, Mazzoil M, McCulloch SD, Fair PA, Bossart GD (2008) Lobomycosis in bottlenose dolphins (Tursiops truncatus) from the Indian River Lagoon, Florida: estimation of prevalence, temporal trends, and spatial distribution. EcoHealth 5:289-297

> Nelson M, Jones SH, Edwards C, Ellis JC (2008) Characterization of Escherichia coli populations from gulls, landfill trash, and wastewater using ribotyping. Dis Aquat Org 81: $53-63$
Norton SA (2006) Dolphin-to-human transmission of lobomycosis? J Am Acad Dermatol 55:723-724

Ofori-Danson PK, Van Waerebeek K, Debrah S (2003) A survey for the conservation of dolphins in Ghanaian coastal waters. J Ghana Sci Assoc 5:45-54

> Ohishi K, Zenitani R, Bando T, Goto Y and others (2003) Pathological and serological evidence of Brucellainfection in baleen whales (Mysticeti) in the western North Pacific. Comp Immunol Microbiol Infect Dis 26: 125-136

> Ohishi K, Takishita K, Kawato M, Zenitani R and others (2004) Molecular evidence of new variant Brucella in North Pacific common minke whales. Microbes Infect 6: 1199-1204

Ohishi K, Maruyama T, Ninomiya A, Kida H and others (2006) Serologic investigation of influenza a virus infection in cetaceans from the western North Pacific and the Southern oceans. Mar Mamm Sci 22:214-221

Paniz-Mondolfi AE, Reyes-Jaimes O, Dávila-Jones L (2007) Lobomycosis in Venezuela. Int J Dermatol 46:180-185

Pearce G, Blacklaws BA, Gajda AM, Jepson PD, Deaville R, Van Bressem MF (2008) Molecular identification and phylogenetic relationships in poxviruses from cetacean skin lesions. In: Pierce GJ, Philips E, Lick R (eds) Proc 22nd ECS Conf, Egmond aan Zee, The Netherlands, 10-12 March 2008. European Cetacean Society, Egmond aan Zee

Plowright W (1982) The effects of rinderpest and rinderpest control on wildlife in Africa. Symp Zool Soc Lond 50: $1-28$

Raga JA, Radúan A, Balbuena JA, Aguilar A, Grau E, Borrell A (1991) Varamientos de cetáceos en las costas españolas del Mediterraneo durante el período 1982-1988. Misc Zool 15:215-226

Raga JA, Banyard A, Domingo M, Corteyn M and others (2008) Dolphin morbillivirus epizootic resurges in the Mediterranean. Emerg Infect Dis 14:471-473

Rector A, Stevens H, Lacave G, Lemey P and others (2008) Genomic characterization of novel dolphin papillomaviruses provides indications for recombination within the Papillomaviridae. Virology 378:151-161

Reif JS, Mazzoil MS, McCullogh SD, Varela R, Goldstein JD, Fair P, Bossart GD (2006) Lobomycosis in Atlantic bottlenose dolphins from the Indian River Lagoon, Florida. J Am Vet Med Assoc 228:104-108

Reif JS, Peden-Adams MM, Romano TA, Rice CD, Fair PA, Bossart GD (2008) Immune dysfunction in Atlantic bottlenose dolphins (Tursiops truncatus) with lobomycosis. Med Mycol 47:125-135

Rosa PS, Soares CT, Belone Ade F, Vilela R, Ura S, Filho MC, Mendoza L (2009) Accidental Jorge Lobo's disease in a worker dealing with Lacazia loboi infected mice: a case report. J Med Case Reports 3:67-72

Ross PSR (2002) The role of immunotoxic environmental contaminants in facilitating the emergence of infectious diseases in marine mammals. Hum Ecol Risk Assess 8: 277-292

Ross HM, Foster G, Reid RJ, Jahans KL, Macmillan AP (1994) Brucella species infection in sea mammals. Vet Rec 134: 359

Ross PSR, Vos JG, Birnbaum LS, Osterhaus ADME. (2000) PCBs are a health risk for humans and wildlife. Science 289:1878-1879

> Rotstein DS, Burdett LG, McLellan W, Schwacke L and others (2009) Lobomycosis in offshore bottlenose dolphins (Tursiops truncatus), North Carolina. Emerg Infect Dis 15: $588-590$ 
Ruiz GM, Rawlings TK, Dobbs FC, Drake LA, Mullady T, Huq A, Colwell RR (2000) Global spread of microorganisms by ships. Nature 408:49-50

Samuels A, Spradling TR (1995) Quantitative behavioral study of bottlenose dolphins in swim-with-dolphin programs in the United States. Mar Mamm Sci 11:520-544

Seidel DJ, Fu Q, Randel WJ, Reichler TJ (2008) Widening of the tropical belt in a changing climate. Nature Geosci 1: $21-24$

Siebert U, Joiris C, Holsbeek L, Benke H, Failing K, Frese K, Petzinger E (1999) Potential relation between mercury concentrations and necropsy findings in cetaceans from German waters of the North and Baltic Seas. Mar Pollut Bull 38:285-295

Simões-Lopes PC, Paula GS, Xavier FM, Scaramelo AC (1993) First case of lobomycosis in bottlenose dolphin on Southern Brazil. Mar Mamm Sci 9:329-331

Smith AW, Skilling DE, Ridgway SH (1983) Calicivirusinduced vesicular disease in cetaceans and probable interspecies transmission. J Aam Vet Med Assoc 11:1223-1225

Sohn A, Probert WS, Glaser CA, Gupta N and others (2003) Human neurobrucellosis with intracerebral granuloma caused by a marine mammal Brucella spp. Emerg Infect Dis 9:485-488

Symmers WS (1983) A possible case of Lobo's disease acquired in Europe from a bottle-nosed dolphin (Tursiops truncatus). Bull Soc Pathol Exot Filiales 76:777-784

Taborda PR, Taborda VA, McGinnins MR (1999) Lacazia loboi gen. nov., comb., the etiologic agent of lobomycosis. J Clin Microbiol 37:2031-2033

Tachibana M, Watanabe K, Kim S, Omata Y, Murata K, Hammond T, Watarai M (2006) Antibodies to Brucella spp. in Pacific bottlenose dolphins from the Solomon Islands. J Wildl Dis 42:412-414

Taubenberger JK, Tsai M, Krafft AE, Lichy JH, Reid AH, Schulman FY, Lipscomb TP (1996) Two morbilliviruses implicated in bottlenose dolphin epizootics. Emerg Infect Dis 2:213-216

> Taubenberger JK, Tsai MM, Atkin TJ, Fanning TG and others (2000) Molecular genetic evidence of a novel morbillivirus in a long-finned pilot whale (Globicephalus [sic] melas). Emerg Infect Dis 6:42-45

Thorne ET, Williams E (1988) Disease and endangered species: the black-footed ferret as a recent example. Conserv Biol 2:66-74

Valsecchi E, Amos W, Raga JA, Podestà M, Sherwin W (2004) The effects of inbreeding on mortality during a morbillivirus outbreak in the Mediterranean striped dolphin (Stenella coeruleoalba). Animal Cons 7:139-146

> Van Bressem MF, Van Waerebeek K (1996) Epidemiology of poxvirus in small cetaceans from the Eastern South Pacific. Mar Mamm Sci 12:371-382

- Van Bressem MF, Visser IK, Van de Bildt MW, Teppema JS, Raga JA, Osterhaus AD (1991) Morbillivirus infection in Mediterranean striped dolphins (Stenella coeruleoalba). Vet Rec 129:471-472

> Van Bressem MF, Visser IKG, De Swart RL, Örvell C and others (1993) Dolphin morbillivirus in different parts of the Mediterranean Sea. Arch Virol 129:235-242

- Van Bressem MF, Van Waerebeek K, Piérard G, Desaintes C (1996) Genital and lingual warts in small cetaceans from coastal Peru. Dis Aquat Org 26:1-10

Van Bressem MF, Jepson P, Barrett T (1998) Further insight on the epidemiology of cetacean morbillivirus in the northeastern Atlantic. Mar Mamm Sci 14:605-613

> Van Bressem MF, Van Waerebeek K, Raga JA (1999) A review of virus infections of cetaceans and the potential impact of morbilliviruses, poxviruses and papillomaviruses on host population dynamics. Dis Aquat Org 38:53-65

Van Bressem M, Waerebeek KV, Jepson PD, Raga JA and others (2001a) An insight into the epidemiology of dolphin morbillivirus worldwide. Vet Microbiol 81:287-304

- Van Bressem MF, Van Waerebeek K, Raga JA, Godfroid J, Brew SD, MacMillan AP (2001b) Serological evidence of Brucella species infection in odontocetes from the South Pacific and the Mediterranean. Vet Rec 148:657-661

Van Bressem MF, Gaspar R, Aznar J (2003) Epidemiology of tattoo skin disease in bottlenose dolphins Tursiops truncatus from the Sado estuary, Portugal. Dis Aquat Org 56:171-179

Van Bressem MF, Cassonnet P, Rector A, Desaintes C and others (2007a) Genital warts in Burmeister's porpoises: characterization of Phocoena spinipinnis papillomavirus type 1 (PsPV-1) and evidence for a second, distantly related PsPV. J Gen Virol 88:1928-1933

Van Bressem MF, Van Waerebeek K, Reyes JC, Félix F and others (2007b) A preliminary overview of skin and skeletal diseases and traumata in small cetaceans from South American waters. Lat Am J Aquat Mamm 6:7-42

- Van Bressem MF, Van Waerebeek K, Aznar J, Raga JA and others (2009a) Epidemiological pattern of tattoo skin disease: a potential general health indicator for cetaceans. Dis Aquat Org 85:225-237

Van Bressem MF, Santos MCdO, Oshima JE (2009b) Skin diseases in Guiana dolphins (Sotalia guianensis) from the Paranaguá estuary, Brazil: a possible indicator of a compromised marine environment. Mar Environ Res 67(2):63-68

Van Waerebeek K, Reyes JC (1994) Post-ban small cetacean takes off Peru: a review. Rep Int Whaling Comm (Spec Iss) 15:503-519

Van Waerebeek K, Van Bressem MF, Félix F, Alfaro J and others (1997) Mortality of dolphins and porpoises in coastal fisheries off Peru and southern Ecuador in 1994. Biol Conserv 81:43-49

Van Waerebeek K, Baker AN, Félix F, Gedamke J and others (2007) Vessel collisions with small cetaceans worldwide and with large whales in the Southern Hemisphere, an initial assessment. Lat Am J Aquat Mamm 6:43-69

> Varsani A, van der Walt E, Heath L, Rybicki EP, Williamson AL, Martin DP (2006) Evidence of ancient papillomavirus recombination. J Gen Virol 87:2527-2531

Vilani-Moreno FR, Lauris JR, Opromolla DV (2004) Cytokine quantification in the supernatant of mononuclear cell cultures and in blood serum from patients with Jorge Lobo's disease. Mycopathologia 158:17-24

Vilela R, Rosa PS, Belone AF, Taylor JW, Diório SM, Mendoza L (2009) Molecular phylogeny of animal pathogen Lacazia loboi inferred from rDNA and DNA coding sequences. Mycol Res 113:851-857

> Visser IKG, Van Bressem MF, De Swart RL, van de Bildt MWG and others (1993) Characterization of morbilliviruses isolated from dolphins and porpoises in Europe. J Gen Virol 74:631-641

> Wells RS, Tornero V, Borrell A, Aguilar A and others (2005) Integrating life-history and reproductive success data to examine potential relationships with organochlorine compounds for bottlenose dolphins (Tursiops truncatus) in Sarasota Bay, Florida. Sci Total Environ 349:106-119

Whatmore AM, Dawson C, Groussaud P, Koylass MS, King A, Shankster SJ (2008) Marine mammal Brucella genotype associated with zoonotic infection. Emerg Infect Dis 14: $517-518$

> Wohlsein P, Puff C, Kreutzer M, Siebert U, Baumgärtner W (2007) Distemper in a dolphin. Emerg Infect Dis 13: 1959-1961 